\title{
Sistem Monitoring Elektrokardiografi Berbasis Aplikasi Android
}

\author{
Theo Wiranadi Hendrata, Achmad Arifin, dan Nada Fitrieyatul Hikmah \\ Jurusan Teknik Elektro, Fakultas Teknologi Industri, Institut Teknologi Sepuluh Nopember (ITS) \\ Jl. Arief Rahman Hakim, Surabaya 60111 \\ E-mail: arifin@ee.its.ac.id
}

\begin{abstract}
Abstrak- Satu dari sepuluh kematian di dunia disebabkan oleh penyakit jantung. Hal ini menjadikan serangan jantung peringkat pertama penyebab kematian di dunia tiap tahunnya. Aktivitas fisik yang berat dan kondisi jantung yang tidak dipantau menyebabkan jantung mengalami kekurangan oksigen, sehingga akhirnya memicu serangan jantung. Terlebih, tanda tanda serangan jantung harus dikenali dan ditangani dengan segera, atau dapat dipastikan akan terjadi kerusakan permanen pada otot jantung yang bila berlangsung lama dipastikan akan berujung pada kematian. Peran pemantauan kondisi jantung ini dapat dilakukan dengan memantau sinyal jantung menggunakan elektrokardiogram

Oleh karena itu dibutuhkan adanya sistem monitoring elektrokadiografi berbasis android. Alat ini berupa elektrokardiogram portabel yang terintegrasi dengan perangkat smartphone. Alat ini bekerja dengan menangkap sinyal jantung melalui elektroda, kemudian diamplifikasi dan difilter, dan diolah di mikrokontroler untuk memperoleh parameter irama jantung sebagai tanda kelelahan jantung. Sinyal tersebut lalu dikirimkan melalui komunikasi bluetooth ke perangkat android. Dari sana dapat diperoleh detak jantung dan zona detak jantung secara spesifik. Dari data tersebut, ketika terdeteksi kelelahan dari irama jantung akan muncul peringatan pada aplikasi perangkat pengguna.

Teknik Pan-Tompkins digunakan untuk deteksi segmen QRS dan interval RR untuk detak jantung, Pada aplikasi android, apabila detak jantung melebihi $80 \%$ dari detak jantung maksimal maka akan timbul peringatan dengan harapan penggunanya dapat beristirahat sejenak agar terhindar dari risiko serangan jantung. Tujuan jangka panjang dari alat ini adalah dapat meningkatkan kewaspadaan penggunanya akan kesehatan jantung dan menurunkan tingkat mortalitas yang disebabkan oleh penyakit jantung.
\end{abstract}

Kata Kunci-android, bluetooth, EKG, elektrokardiografi, jantung, mikrokontroler, irama jantung

\section{PENDAHULUAN}

$\mathrm{T}$ EKNOLOGI di bidang teknik biomedik pada era ini sudah berkembang pesat. Teknologi kesehatan baru yang bersifat kuratif banyak bermunculan. Sayangnya, teknologi yang bersifat preventif masih kurang diperhatikan. Hal ini terlihat pada kasus penyakit jantung. Menurut World Health Organization, pada tahun 2012 saja, 7,4 juta orang di seluruh dunia meninggal karena penyakit jantung [1]. Salah satu penyebabnya adalah beratnya aktivitas yang dilakukan sehingga menyebabkan jantung mengalami kelelahan dan kekurangan oksigen. Terlebih lagi, pada aktivitas tersebut kondisi jantung seringkali tidak terpantau, sehingga kasus serangan jantung tidak dapat tertangani dengan cepat.

Di dalam dunia medis sendiri terdapat teorema waktu kritis yang lebih dikenal dengan "Golden Period". Istilah tersebut menandakan waktu kritis maksimal penanganan pasien sebelum terjadi kerusakan permanen dan kematian. Berdasarkan teori ini, kemungkinan penderita selamat dari serangan jantung mendekati nol bila ditangani setelah 10 menit sejak serangan jantung pertama terjadi [2].

Pemeriksaan kondisi jantung sebenarnya sudah dapat dilakukan dengan menggunakan metode elektrokardiografi. Elektrokardiograf atau EKG dapat digunakan untuk memonitor sinyal biopotensial yang ditimbulkan jantung [3]. Sayangnya, elektrokardiograf umumnya hanya tersedia di rumah sakit karena biayanya yang tergolong mahal. Karena ketersediaannya juga terbatas, pasien diharuskan menyewa alat ini, dan harus konsultasi ke dokter secara berkala. Tarif yang tinggi dan proses yang rumit ini menyebabkan pasien enggan memeriksakan kondisi jantungnya apabila tidak merasakan keluhan berarti. Padahal indikasi serangan jantung seringkali tidak disadari atau diabaikan.

Oleh karena itu, diperlukan adanya elektrokardiograf portabel yang terintegrasi dengan perangkat komunikasi cerdas dapat memantau secara kontinu agar aktivitas jantung dapat dipantau. Alat ini harus dapat menjadi alat pengawas irama jantung secara otomatis dan kontinu, sehingga diharapkan mampu menghindarkan penggunanya dari kematian, dan mempersingkat waktu respons terhadap serangan jantung, sehingga dalam jangka panjang alat ini dapat meningkatkan kewaspadaan akan kesehatan jantung dan menurunkan tingkat mortalitas yang disebabkan oleh penyakit jantung.

\section{METODE PENELITIAN}

\section{A. Aktivitas dan Kelelahan Fisik}

Aktivitas fisik dapat diklasifikasikan menjadi dua, yaitu aerobik dan anaerobik. Aktivitas aerobik adalah kegiatan dengan intensitas rendah, yang dapat dilakukan untuk jangka waktu lama. Sumber energinya diperoleh dari nutrisi dan oksigen. Di lain sisi, aktifitas anaerobik menggunakan tenaga besar untuk jangka waktu pendek dengan membakar glikogen yang tersimpan dalam otot. Membakar glikogen tanpa oksigen melepaskan asam laktat yang menyebabkan kelelahan fisik. Aktivitas ini tidak dapat dilakukan untuk jangka waktu lama, dan harus ada jeda untuk pemulihan. Kemungkinan terjadinya 
serangan jantung jauh lebih tinggi saat beraktivitas berat daripada saat beristirahat, dan terlebih lagi, penelitian membuktikan bahwa serangan jantung merupakan penyebab utama kematian saat berolah raga.

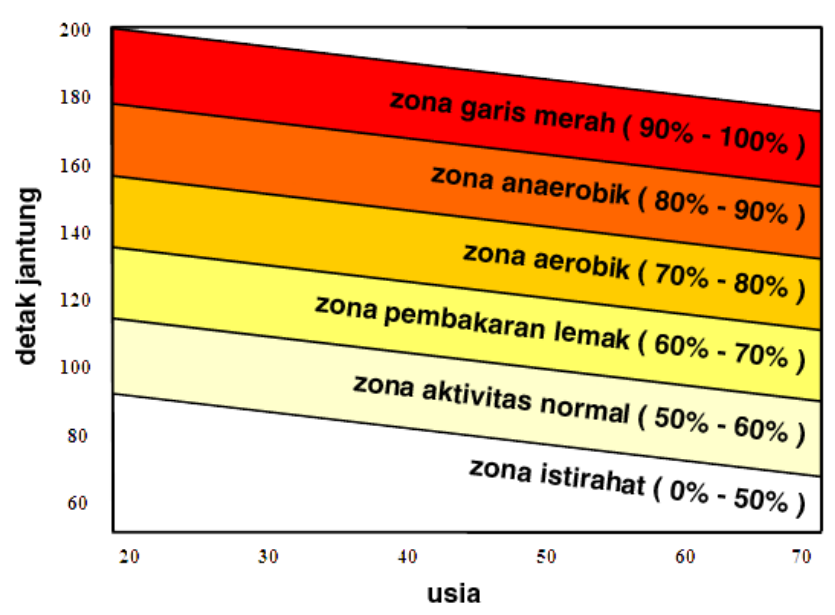

Gambar 1. Zona Aktifitas Fisik terhadap Irama Jantung

Oleh karena itu, aktivitas anaerobik tidak dapat dilakukan untuk jangka waktu lama; dan harus ada jeda pemulihan setiap beberapa saat. Aktivitas statis seperti angkat besi atau aktivitas intensitas tinggi seperti mendaki, berlari sprint, adalah contoh latihan anaerobik. Pasien dengan risiko jantung tidak boleh melakukan latihan ini karena dapat memicu terjadinya serangan jantung.

Irama jantung manusia dewasa saat beristirahat antara berkisar 60-100 bpm. Irama jantung yang cepat disebut dengan takikardia, terjadi bila detak jantungnya di atas 100 bpm saat istirahat. Bradikardia adalah irama jantung yang lambat, di bawah $60 \mathrm{bpm}$ saat istirahat. Selama tidur jantung berdetak lebih lambat dengan irama sekitar 40-50 bpm.

Irama jantung saat beraktivitas dibagi menjadi beberapa zona yang dapat dilihat pada Gambar 1. Detak jantung maksimal sendiri dapat dikalkulasi dengan rumus Karvonen MaxHR $=220-$ usia. Zona pertama apabila detak jantung berada di bawah $50 \%$ dari detak jantung maksimum, maka kondisi dapat dikategorikan sebagai istirahat, dengan risiko serangan jantung normal atau sangat kecil pada orang sehat.
Zona kedua pada 50\%-60\% detak jantung maksimal, maka aktivitas dikategorikan sebagai aktivitas ringan sehari hari. Zona ketiga pada 60\%-70\%, maka aktivitas dikategorikan sebagai aktivitas pemulihan, atau pembakaran lemak.

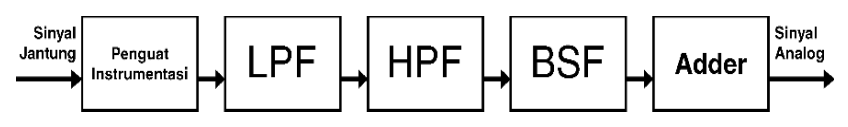

Gambar 2. Diagram Blok Rangkaian Elektrokardiogram

Pada zona ini ketahanan fisik terbentuk, sehingga baik untuk kesehatan. Pada zona 70\%-80\% adalah zona aerobik. Zona ini cocok sebagai target irama jantung saat berolahraga, karena pada zona ini peredaran darah lancar dan tubuh beraktivitas secara maksimal. Pada zona 80\%-90\% dari detak jantung maksimal, tubuh mulai memasuki zona anaerobik. Pada zona ini aktivitas yang terjadi akan menggunakan energi yang tersimpan pada otot, bukan dari lemak. Zona ini berbahaya bila dilakukan dengan jangka lama karena dapat menyebabkan kelelahan otot dan menaikkan risiko serangan jantung. Pada zona 90\%-100\% dari detak jantung maksimal, semua sumber energi tubuh akan terkuras, dan terjadi kelelahan yang ekstrim. Zona ini disebut juga dengan zona garis merah atau zona intensitas tinggi karena menggunakan oksigen maksimal dalam tubuh. Hal ini berbahaya karena dapat memicu serangan jantung iskemik secara langsung. Atlet yang berpengalaman sekalipun hanya boleh berada di zona ini untuk waktu yang sangat singkat [4],[5],[6].

\section{B. Pemrosesan Sinyal Analog}

Sinyal kelistrikan yang dikeluarkan oleh jantung dapat dibaca dengan metode elektrokardiografi. Prinsip kerja elektrokardiograf atau EKG dapat dilihat pada Gambar 2, sedangkan skematik lengkapnya pada Gambar 3.

Pada rangkaian EKG tujuan utama rangkaian adalah merubah sinyal dari sinyal jantung yang memiliki amplitudo kecil dan memiliki banyak noise menjadi sinyal jantung analog yang bersih dari noise dan memiliki amplitudo yang cukup besar dengan tegangan minimum di atas nol agar dapat dimasukkan dan dibaca dengan benar oleh mikrokontroler. Pertama-tama sinyal dari tubuh ditangkap oleh tiga buah

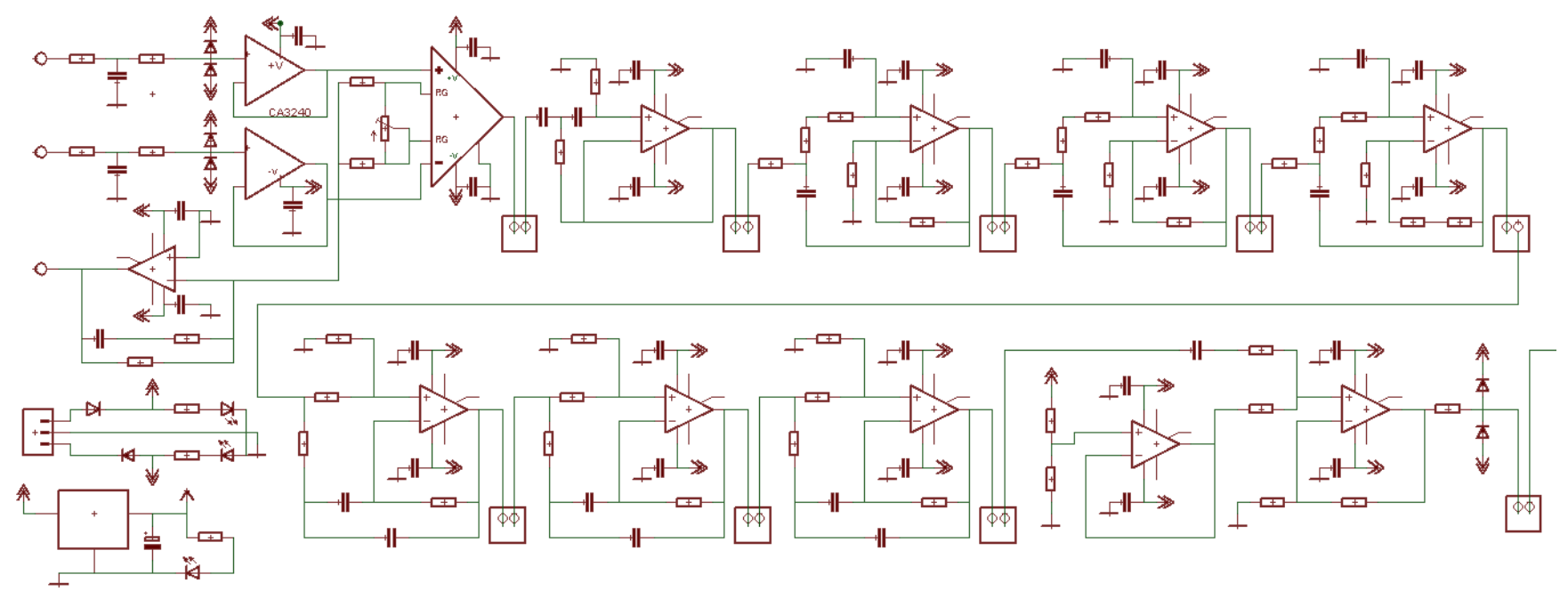

Gambar 3. Skematik rangkaian analog, tediri dari penguat instrumentasi AD620 dengan buffer CA3240 dan drive right leg, 1 stage high pass filter, 3 stage low pass filter, 3 stage band pass filter, dan rangkaian penjumlah tak membalik dengan buffer tegangan referensi. 
elektroda yang dipasang berdasarkan teorema Einthoven 3 lead, Left Arm, Right Arm, dan Left Leg. Ketiga elektroda itu mewakili elektroda ekstermitas yang diletakkan di dada penggunanya.

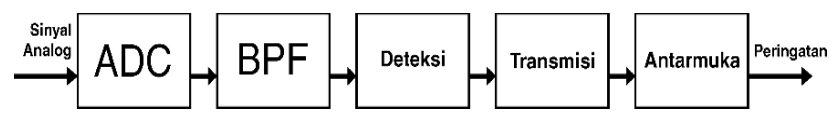

Gambar 4. Diagram Blok Piranti Lunak

Sinyal dilanjutkan ke penguat instrumentasi untuk membesarkan sinyal yang awalnya hanya memiliki amplitudo orde milivolt hingga menjadi sinyal dengan orde volt. Setelah melewati penguatan, noise dihilangkan dengan menggunakan rangkaian filter dengan menggunakan topologi Sallen-Key dengan orde 2. Rangkaian High Pass Filter digunakan untuk meredam interferensi sinyal listrik otot dan tegangan DC drift, didesain dengan frekuensi cut-off $0,05 \mathrm{~Hz}$. Setelah itu digunakan Low Pass Filter untuk meredam noise dari interferensi RF dan anti aliasing ketika disampling, didesain dengan menggunakan 3 tahapan agar dapat meredam dengan sempurna. Frekuensi cut-off LPF ditetapkan pada $100 \mathrm{~Hz}$. Untuk meredam interferensi sinyal jala-jala digunakan Band Stop Filter dengan frekuensi cut-off $50 \mathrm{~Hz}$ sebanyak 3 tahapan. Sinyal EKG memiliki rentang tegangan hingga polaritas negatif, yang tidak dapat dibaca oleh mikrokontroler. Rangkaian Non Inverting Adder digunakan untuk menaikkan sinyal hingga nilai minimumnya di atas nol. Untuk penjumlahan sinyal digunakan sumber dari pembagian tegangan dengan resistor variabel [7],[8].

\section{Pemrosesan Sinyal Digital}

Pemrosesan sinyal digital dapat dilihat pada Gambar 4. Pertama tama sinyal jantung yang berbentuk analog dari rangkaian EKG dikonversi menjadi sinyal digital dengan Analog to Digital Converter. Fitur ADC yang digunakan menggunakan sistem 8 bit sehingga resolusinya dapat dihitung pada Persamaan (1).

$$
\text { resolusi } A D C=\frac{\text { wrej }}{2^{2}-1}=\frac{3000 \mathrm{mV}}{255}=11.764 \mathrm{mV} / \mathrm{bit}
$$

Setelah disampel, rangkaian dilewatkan pada band pass filter dengan mode Infinite Impulse Response. Filter ini berfungsi untuk melewatkan segmen sinyal yang memiliki bandwidth tertentu, yaitu segmen kompleks QRS dan segmen ST. Digunakan parameter panjangnya $R$ dan besarnya sudut teta atau $\theta$ yang dapat dirumuskan pada Persamaan (2).

$$
y(n)=x(n)-x(n-2)+2 \cos \theta r y(n-1)-r^{2} y(n-2)
$$

Setelah dilewatkan band pass filter maka sinyal dapat dideteksi dan disegmentasi. Deteksi sinyal dilakukan menggunakan modifikasi dari algoritma Pan-Tompkins. Algoritma yang digunakan adalah squaring, moving window, dan thresholding. Pada tahapan squaring semua sinyal dikuadratkan dengan tujuan mendapatkan keluaran yang tinggi dan positif dengan rumus Persamaan (3).

$$
y[n]=x[n] \times x[n]=(x[n])^{2}
$$

Tahapan moving window integral atau moving average filter. digunakan untuk memperhalus sinyal, dapat dituliskan dengan rumus Persamaan (4)

$$
y[n]=\frac{1}{M} \sum_{j=0}^{M-1} x[n-j]
$$

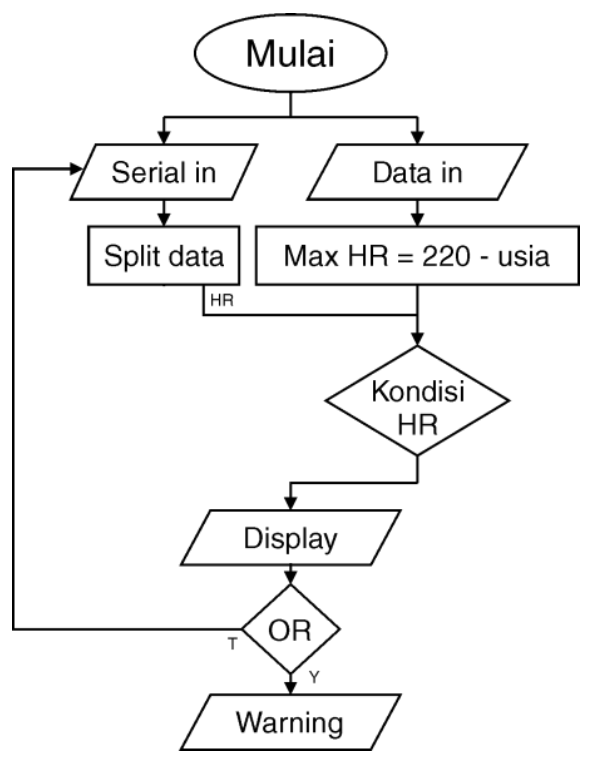

Gambar 5. Algoritma antarmuka dan peringatan

Tabel 1.

Kondisi jantung berdasarkan detak jantung

\begin{tabular}{ccc}
\hline \hline $\begin{array}{c}\text { Persentase dari HR } \\
\text { maskimal }\end{array}$ & Zona & Kondisi Jantung \\
\hline$<50 \%$ & Aman & Istirahat \\
$50 \%-60 \%$ & Aman & Aktivitas \\
$60 \%-70 \%$ & Siaga & Olahraga \\
$70 \%-80 \%$ & Waspada & Aerobik \\
$>80 \%$ & Bahaya & Anerobik \\
\hline \hline
\end{tabular}

Tahap thresholding digunakan sebagai deteksi segmen. Jika sinyal lebih besar dari threshold maka segmen terdeteksi. Sehingga dapat ditulis sebagai Persamaan (5)

$$
y[n]=\left\{\begin{array}{l}
1, x[n]>\text { threshold } \\
0, x[n]<\text { threshold }
\end{array}\right]
$$

Untuk mendeteksi tepi naik dicari nilai kenaikan dimana nilai masukkan sebelumnya lebih kecil dari ambang batas threshold atau dapat dituliskan pada Persamaan (6)

$$
y[n]=\left\{\begin{array}{ll}
1, x[n]>\text { threshold } n x[n-1]<\text { threshold } \\
0, & \text { lainnya }
\end{array}\right\}
$$

Untuk segementasi kompleks QRS dihitung jarak $R-R$ interval dapat dihitung dengan menghitung jarak tepi naik tersebut. Setelah jarak diketahui, jarak yang masih memiliki satuan sampel tersebut diubah menjadi nilai heart rate dengan rumus Persamaan (7) 


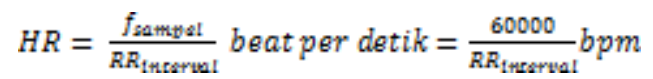

Nilai detak jantung dikirimkan menuju smartphone dengan komunikasi serial. Sistem transmisi data dilakukan dengan nirkabel menggunakan perangkat Bluetooth dengan modul HC05. Setelah ditransmisikan, pada smartphone pengguna dibuat aplikasi dengan fungsi sebagai interface utama dan sistem peringatan. Pertama tama data diterima melalui komunikasi serial. Data kemudian dipisah untuk dikomputasi.

Maximal heart rate dihitung dengan rumus $H R_{\text {maks }}=220-$ usia. Setelah itu dianalisa zona detak jantung yang dapat dilihat pada Tabel 1. Keadaan jantung akan dimonitor secara kontinyu dari aplikasi. Apabila salah satu kondisi mengalami indikasi bahaya maka akan keluar peringatan pada smartphone pengguna diagram sistem peringatan dapat dilihat pada Gambar 5 [8],[9],[10],[11].

\section{HASIL DAN DISKUSI}

\section{A. Pengujian Perangkat Elektrokardiograf}

Pengujian dan analisa perangkat elektrokardiograf dibagi menjadi beberapa bagian, yaitu pengujian penguat instrumentasi, Low Pass Filter, High Pass Filter, Band Stop Filter, rangkaian penjumlah.

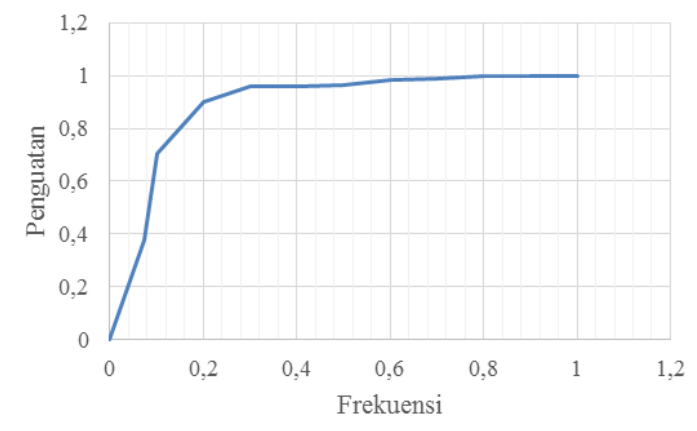

(a)

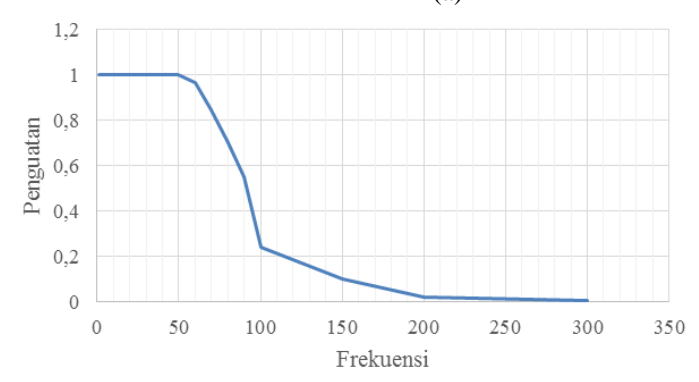

(b)

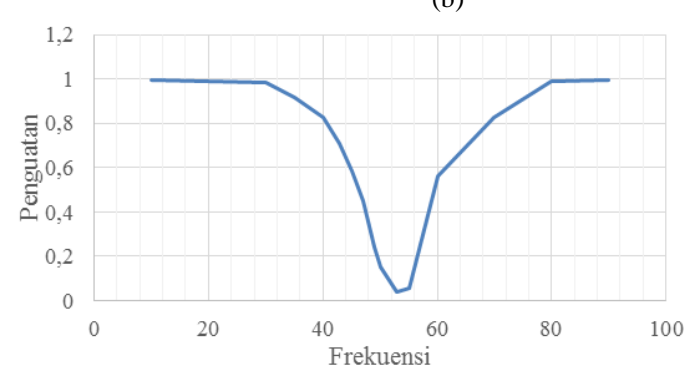

(c)

Gambar 7. Grafik Hasil Pengujian Filter (a) High Pass Filter (b) Low Pass Filter (c) Band Stop Filter
Tabel 2.

Hasil Pengujian Filter

\begin{tabular}{cccc}
\hline \hline Filter & HPF & LPF & BSF \\
\hline cutoff ideal $(\mathrm{Hz})$ & 0.1 & 100 & 50 \\
cutoff real $(\mathrm{Hz})$ & 0.05 & 80 & 51.9 \\
Pergeseran $(\mathrm{Hz})$ & 0.05 & 20 & 1.9 \\
penguatan passband & 1 & 1 & 0.995 \\
\hline \hline
\end{tabular}

Pengujian penguat instrumentasi dilakukan dengan memasukkan sinyal masukan sinusoidal dengan amplitudo kecil, kemudian sinyal dikuatkan dengan rangkaian instrumentasi sehingga diperoleh besar penguatan rangkaian. Pengujian filter dilakukan dengan memberi sinyal masukkan sinyal sinus dengan amplitudo yang sama pada frekuensi berbeda beda. Pengujian rangkaian penjumlah dilakukan dengan memberikan masukkan berbagai macam sinyal dengan berbagai macam tegangan dan frekuensi dan dilihat kenaikan tegangannya. Dari hasil pengujian dapat diperoleh penguatan total mendekati 1000 kali dengan kenaikan tegangan 1 volt. Pada pengujian filter dapat dilihat bahwa bentuk filter menyerupai teori, namun terdapat pergeseran frekuensi cutoff. Hasil pengujian filter dapat dilihat pada Gambar 7 dan Tabel 2.

\section{B. Pengujian Pemrosesan Sinyal}

Pengujian segmentasi dilakukan dengan menggunakan band pass filter dengan tipe infinite impulse response (IIR) dengan orde 2. Pada filter ini digunakan frekuensi cutoff $3 \mathrm{~Hz}$ dan bandwidth frekuensi $1 \mathrm{~Hz}$. Pemilihan frekuensi tersebut didasarkan dari transformasi sinyal jantung dari domain waktu ke domain frekuensi. Pengujian komputasi data dilakukan untuk mendeteksi kompleks QRS. Pengujian dilakukan dengan merekam sinyal jantung dari elektrokardiograf dan ditransmisikan ke komputer. Sinyal digital ini kemudian direkonstruksi kembali agar dapat melihat bentuk sinyal dan menghitung ketepatan sinyal. Hasilnya dapat dilihat pada Gambar 8.

Dari gambar ini dapat dilihat bahwa sinyal keluaran rangkaian sesuai dengan fungsi tiap proses sinyal, yakni derivative, squaring, moving window integral, dan thresholding. Pada proses derivative sinyal diturunkan sehingga menjadi gradien. Setelah itu pada squaring sinyal dikuadratkan sehingga menjadi positif. Pada moving window integral sinyal dirata-rata sehingga menjadi lebih halus. Pada thresholding sinyal diberi ambang batas sehingga hanya terdeteksi ketika titik R. Pengujian juga dilakukan untuk memeriksa apakah detak jantung yang terukur sesuai dengan detak jantung sebenarnya. Oleh karena itu sinyal jantung yang telah diproses secara analog dimasukkan ke dalam osiloskop untuk dihitung secara manual dan dibandingkan. Hasilnya terlihat pada Tabel 3 dengan kesalahan rata rata $2 \%$. 


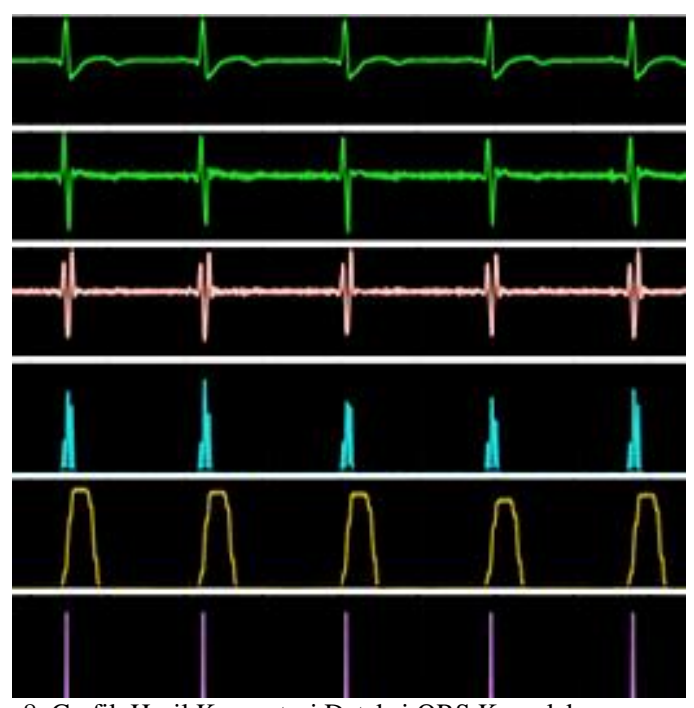

Gambar 8. Grafik Hasil Komputasi Deteksi QRS Kompleks

Tabel 3.

Hasil Perhitungan Detak Jantung

\begin{tabular}{cccc}
\hline \hline $\begin{array}{c}\text { HR } \\
\text { komputasi } \\
(\mathrm{bpm})\end{array}$ & $\begin{array}{c}\text { RR } \\
\text { interval }\end{array}$ & $\begin{array}{c}\text { HR } \\
\text { pengukuran } \\
(\mathrm{bpm})\end{array}$ & $\begin{array}{c}\text { Error } \\
(\%)\end{array}$ \\
\hline 68 & 860 & 69,76744 & 2,533333 \\
70 & 870 & 68,96552 & 1,5 \\
73 & 840 & 71,42857 & 2,2 \\
69 & 855 & 70,17544 & 1,675 \\
78 & 745 & 80,53691 & 3,15 \\
75 & 780 & 76,92308 & 2,5 \\
75 & 815 & 73,61963 & 1,875 \\
76 & 775 & 77,41935 & 1,833333 \\
73 & 850 & 70,58824 & 3,41667 \\
72 & 820 & 73,17073 & 1,6 \\
\hline \hline
\end{tabular}

Algoritma peringatan diujikan dengan menghubungkan perangkat android dengan alat. Pengujian pertama dilakukan dengan memasukkan data pengguna, dan mengirimkan data serial untuk menguji algoritma yang ada. Dari hasil pengujian dapat dianalisa bahwa sistem algoritma dan antarmuka aplikasi berjalan dengan baik. Apabila detak jantung lebih besar dari $80 \%$ dari detak jantung maksimal maka muncul peringatan pada smartphone pengguna. Pengujian algoritma peringatan dilakukan dengan memberi distorsi sinyal pada elektroda sehingga keluaran sinyalnya terdistorsi dan memberikan false positive. Dari perangkat pengguna dapat dilihat bahwa ada peringatan yang muncul. Dari hasil monitoring dapat disimpulkan bahwa sistem dapat berjalan dengan baik.

\section{Pengujian Sistem Keseluruhan}

Pengujian sistem keseluruhan dimulai dari perangkat elektrokardiograf, pemrosesan sinyal digital, transmisi data, dan algoritma peringatan. Pengujian dilakukan dengan memasang elektroda pada dada dengan metode sadapan III Einthoven. Sadapan ini dipasang di tiga titik, dada kanan (RA) dan dada kiri (LA) di antara areola dengan bahu, dan dada bawah (LL) di sternum kiri terakhir, seperti yang terlihat pada Gambar 9a. Elektroda yang digunakan adalah elektroda tempel disposable. Rangkaian elektrokardiograf kemudian digunakan dan dinyalakan, dan kemudian subyek melanjutkan aktivitas. Alat kemudian dikoneksikan dengan smartphone dengan koneksi bluetooth.

Sembari pengguna melakukan aktivitas sehari hari, alat elektrokardiograf memantau sinyal jantung pengguna seperti Gambar 9b. Sinyal elektrokardiograf diuji menggunakan osiloskop yang dipasang di keluaran akhir perangkat keras pada adder. Hasil sinyal tersebut dibandingkan dengan sinyal yang terbaca pada layar LCD mikrokontroler, dan dapat dilihat pada Gambar 9c dan 9d. Dari hasil pengujian dapat dilihat bahwa sinyal keluarannya serupa. Dari mikrokontroler diperoleh nilai detak jantung ST yang dikirimkan ke perangkat pengguna. Dari perangkat pengguna terlebih dahulu dimasukkan data pengguna, dan dihitung parameter detak jantung maksimalnya. Tampilan data dapat dilihat pada Gambar 9e. Apabila terjadi deteksi bahaya akan timbul peringatan seperti Gambar 9f.
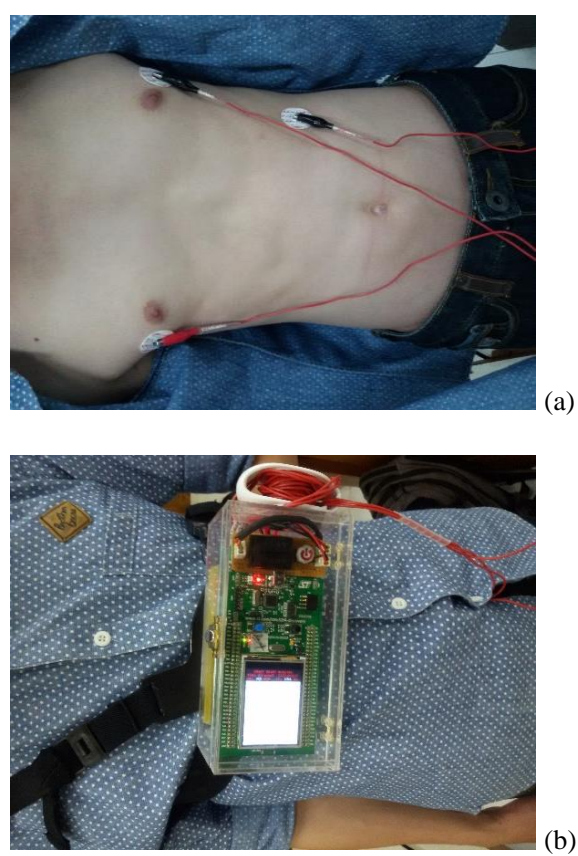

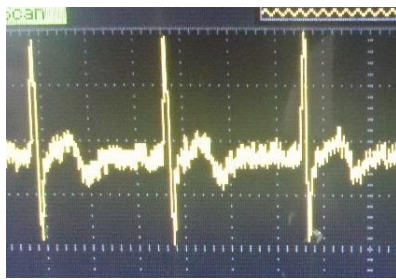

(c)

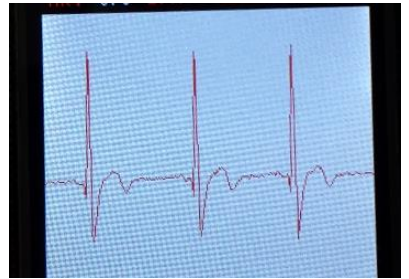

(d) 


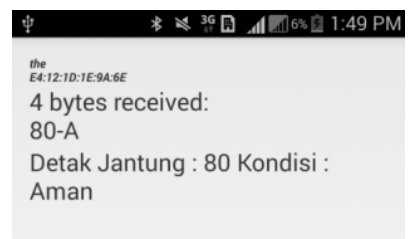

(e)

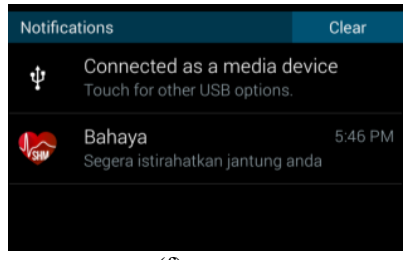

(f)
Gambar 9. Hasil pengujian sistem keseluruhan (a) Pemasangan Elektroda (b) Rangkaian Elektrokardiogram (c) Sinyal Keluaran pada Osiloskop (d) Sinyal Keluaran pada Mikrokontroler (e) Tampilan Data Monitoring pada Smartphone (f) Tampilan Peringatan pada Smartphone

Tabel 4.

Hasil Pengujian Subjek

\begin{tabular}{ccccccc}
\hline \hline $\begin{array}{c}\text { Sub } \\
\text { jek }\end{array}$ & $\begin{array}{c}\text { HR } \\
\text { Max }\end{array}$ & HR & $\begin{array}{c}\text { HR } \\
\text { rest }\end{array}$ & $\begin{array}{c}\text { Error } \\
(\%)\end{array}$ & $\begin{array}{c}\text { Kondisi } \\
\text { Jantung } \\
(\%)\end{array}$ & $\begin{array}{c}\text { Kondisi } \\
\text { Jantung }\end{array}$ \\
\hline 1 & 198 & 74 & 72 & 2,70 & 0,37 & Aman \\
2 & 198 & 87 & 89 & 2,29 & 0,44 & Aman \\
3 & 199 & 80 & 82 & 2,50 & 0,40 & Aman \\
4 & 199 & 67 & 65 & 2,98 & 0,34 & Aman \\
5 & 199 & 89 & 90 & 1,12 & 0,45 & Aman \\
6 & 198 & 83 & 92 & 10,84 & 0,42 & Aman \\
7 & 168 & 65 & 61 & 6,15 & 0,39 & Aman \\
8 & 171 & 79 & 70 & 11,39 & 0,46 & Aman \\
9 & 178 & 70 & 74 & 5,71 & 0,39 & Aman \\
10 & 202 & 83 & 80 & 3,61 & 0,41 & Aman \\
11 & 140 & 101 & 110 & 8,91 & 0,72 & Sedang \\
12 & 144 & 69 & 71 & 2,89 & 0,48 & Aman \\
13 & 172 & 70 & 66 & 5,71 & 0,41 & Aman \\
\hline \hline
\end{tabular}

Hasil pengujian subjek dapat dilihat pada Tabel 4. Dari hasil monitoring dapat disimpulkan bahwa sistem dapat berjalan dengan baik. Pengambilan data kemudian dilakukan dengan mengambil data dari belasan subjek dengan usia, jenis kelamin, dan body mass index yang berbeda beda. Dari data pengujian secara keseluruhan dapat ditarik beberapa poin penting. Pertama, seluruh data pengujian menampilkan sinyal dengan morfologi sama, gelombang $\mathrm{T}$ yang tampak invers tidak menjadi masalah karena segmentasi digunakan dengan flter. Pengujian pada subjek berjenis kelamin perempuan lebih sulit karena penempatan elektroda di dada terhalang oleh busana dan adanya kelenjar mamae, sehingga sinyal yang keluar menimbulkan false negative atau tidak keluar nilai yang sesuai dengan detak jantung walaupun sinyal sidah keluar.

Sebagai catatan, elektroda tempel disposable hanya dapat digunakan kurang lebih tiga kali penempelan, untuk menjaga kualitas sinyal yang dihasilkan. Pada pasien aritmia perlu ditambahkan algoritma untuk rata rata agar hasil pengukuran detak jantung tidak menimbulkan false positive. Pada subjek
11 diambil data dengan subjek yang berusia lanjut dengan riwayat penyakit jantung $A V$ block dan aritmia. Dari data pengujian dapat dilihat bahwa persentase kondisi jantung terhadap detak jantung maksimal termasuk tinggi, dan timbul peringatan pula pada aplikasi. Hal ini terjadi karena subjek tidak meminum obat medikasi yang telah diresepkan dokter, dan subjek tidak melakukan konsultasi dengan dokter dalam beberapa bulan terakhir. Berdasarkan data pengujian satu hingga 13 dapat dilihat bahwa error perhitungan detak jantung memiliki rata rata 5,14\%. Hal ini terjadi karena adanya perbedaan ketelitian antara pengukuran secara langsung melalui denyut nadi dengan menggunakan perhitungan rata rata.

\section{KESIMPULAN}

Berdasarkan perancangan, pengujian, dan analisa sistem dapat ditarik beberapa kesimpulan dari tugas akhir ini.

Pertama, penguatan instrumentasi menggunakan AD620 dengan diatur penguatan 1000 kali untuk memperbesar sinyal jantung yang memiliki orde milivolt. Rangkaian filter dengan orde 2 dan topologi Sallen-Key digunakan untuk meredam noise, oleh karena itu digunakan high pass filter dengan frekuensi cutoff $0,1 \mathrm{~Hz}$, low pass filter dengan frekuensi cutoff $80 \mathrm{~Hz}$, dan band stop filter dengan frekuensi cutoff $51,9 \mathrm{~Hz}$. Agar dapat diproses secara digital sinyal dinaikkan ke polaritas positif dengan memberi tegangan offset melalui rangkaian penjumlah tak membalik.

Ketika sinyal jantung memasuki mikrokontroler, sinyal dikonversi menjadi digital dengan resolusi 8 bit, dan frekuensi sampling $1 \mathrm{kHz}$. Pemrosesan sinyal membutuhkan waktu $132 \mu$ s atau $12,2 \%$ dari waktu total sehingga pehitungan dapat dilakukan dengan real-time. Untuk mendeteksi segmen QRS kompleks dapat digunakan band pass filter, dan teorema PanTompkins untuk memperoleh $R R$ interval. Setelah itu dikomputasikan hingga menemukan detak jantung penggunanya. Data dikirim dengan bluetooth dengan jarak konektivitas 5 meter tanpa halangan. Pada aplikasi smartphone peringatan dapat dilakukan dengan aplikasi, dimana apabila detak jantung melebihi $80 \%$ dari detak jantung maksimal maka akan timbul peringatan.

Berdasarkan hasil pengujian dapat disimpulkan bahwa sistem dapat bekerja dengan baik sesuai dengan rancangan. Hasil pembacaan irama jantung sesuai dengan teorema dengan eror rata rata 5 persen, hanya terjadi false positive ketika ada distorsi pada sinyal. Terakhir, alat ini dapat digunakan selama 11,5 jam dari tegangan penuhnya, dengan konsumsi daya total 173,6 miliwatt.

\section{DAFTAR PUSTAKA}

[1]World Health Organization, "The Global Burden of Disease", WHO, 2004.

[2] American College of Surgeons, "Advanced Trauma Life Support Program for Doctors" Amer College of Surgeons, 2008

[3] Tompkins, Willis, "Biomedical Digital Signal Processing", Prentice Hall, 1995

[4]Guyton, Arthur C., "Textbook of Medical Physiology", 11 $1^{\text {th }}$ edition Elsevier Inc., 2006

[5]Khan, M. Gabriel, "Encyclopedia of Heart Diseases", Elsevier, 2006 
[6]Pakpahan, H.A.P., "Elektrokardiografi Ilustratif: Belajar EKG dengan Ilustrasi Sederhana”, Badan Penerbit Fakultas Kedokteran Universitas Indonesia, 2012.

[7]Pujiono, "Rangkaian Elektronika Analog", Graha Ilmu, 2006

[8]Hanif Messa "Rancang Bangun Sistem Instrumentasi dan Pengolahan Digital Sinyal ECG untuk Analisa Variabilitas Parameter Temporal Berbasis Mikrokontroler ARM", Institut Teknologi Sepuluh Nopember, 2015

[9]Setya, Vinda, "Sistem Monitoring Heart Rate untuk Latihan Treadmill berbasis Mikrokontroler ARM dengan Antarmuka Nirkabel", Institut Teknologi Sepuluh Nopember, 2015

[10] Fitrieyatul, Nada, "Analisis Multimodal Sinyal Jantung (ECG, PCG, dan Carotid Pulse) untuk Klasifikasi Jantung Normal dan Abnormal”, Institut Teknologi Sepuluh Nopember, 2016

[11]Weisner, Steven J., Tompkins, Willis J., Tompkins, Bonnie M., "A Compact, Microprocessor-Based ECG ST-Segment Analyzer for the Operating Room", IEEE Transactions On Biomedical Engineering, Vol. Bme-29, No. 9, September 1982 